\title{
Dietary Supplements as an Object of Civil Legal Relations in Russia
}

Yury Alexandrovich Svirin ${ }^{1}$, Alexandr Anatolievich Mokhov ${ }^{2}$, Vladimir Viktorovich Kulakov³, Vladimir Aleksandrovich Gureev ${ }^{4}$, Svetlana Viktorovna Shimanskaya ${ }^{5}$

${ }^{1}$ Doctor of Legal Sciences, Professor, All-Russian State University of Justice, Russia, ${ }^{2}$ Doctor of Legal Sciences, Professor, Kutafin Moscow State Law University, Russia, ${ }^{3}$ Doctor of Legal Sciences, Professor, The Russian State University of Justice, Russia, ${ }^{4}$ Doctor of Legal Sciences, Professor, All-Russian State University of Justice, Russia,

${ }^{5}$ Senior Lecturer, Academy of Law Management of the Federal Penitentiary Service of Russia, Russia

\begin{abstract}
This paper reviews the legal regulation of the dietary supplement turnover in Russia. Since dietary supplements are an independent object of civil commerce, they must have certain qualities that distinguish them, most importantly, from medicines. According to the authors, the dichotomy in the definition of dietary supplements in the Russian legislation does not allow fully preventing dietary supplements from being confused with other food products, medicines, international non-proprietary names of medicines. The authors also examine the relationship of dietary supplements with such concepts as comestibles and food products.
\end{abstract}

Method: The authors used the method of comparative and systemic analysis, synthesis, and scientific research of the object as an element of civil legal relations.

The purpose of the study was to look at dietary supplements as a subject of civil legal relations, to identify problems of protecting dietary supplements as objects of intellectual property law.

Results: Although since the mid-1990s, active distribution of dietary supplements has begun in Russia, to date, the legal doctrine has not developed the scientific concept of dietary supplements, and the definitions contained in regulatory acts are contradictory. The analysis of the regulatory framework and judicial practice gives reason to conclude that dietary supplements are recognized as objects of civil legal relations in Russia. They are sold in free circulation, they are movable property, and legislators have established mandatory registration for putting these objects into commodity circulation.

Keywords: Object of civil legal relations; dietary supplements; medicines; food products; product life cycle.

\section{Introduction}

The history of the development of the legal regulation of dietary supplements (further referred to as DS) in Russia has developed in line with the legal regulation of the entire pharmaceutical market. In the mid-1990s,

\section{Corresponding Author:}

Yury Alexandrovich Svirin

2/1 Asovskaya Street, Moscow, 117638, Russia

e-mail: yury.svirin@bk.ru the country began an active distribution of nutritional supplements, with Herbalife as the largest supplier. In 1991, the Russian legislators adopted law No. 1034-1 "On the sanitary and epidemiological well-being of the population," of the Russian Soviet Federative Socialist Republic (RSFSR) which was the foundation for the legal regulation of DS production and circulation. However, this was the first step, not entirely successful, to create a legal framework for the DS production and civil commerce.

Currently, Russia is completing the implementation of the Strategy for the Development of the Pharmaceutical 
Market of the Russian Federation until 2020. The goal of the strategy was the transition to an innovative model for the development of the pharmaceutical industry of the Russian Federation. This is expected to be achieved through consistent technical and technological reequipment of enterprises and the release of innovative products, including DS, demanded by the population. As a result, by 2020, the export potential of Russian pharmaceutical products should exceed the figure of 2008 by 8 times. However, not all goals have been achieved, which forces us to carefully study the ongoing processes and draw the right conclusions.

Today, the Federal DS Register of the Federal Service for Surveillance on Consumer Rights Protection and Human Wellbeing (Rospotrebnadzor) lists about 9,500 DS ${ }^{1}$. For example, in 2018 alone, Rospotrebnadzor issued 2,302 certificates of state registration for DS. For many years now, the Evalar company has remained the market leader. The second place is occupied by PharmaMed. According to data for 9 months of 2018, there were more than 52 thousand facilities in the Russian Federation engaged in the production and commerce of DS, including 180 enterprises engaged in DS production and 52,029 enterprises engaged in DS circulation (including 735 warehouses, 5,569 retail network enterprises, 45,725 pharmacy chain facilities). At the same time, according to the results for 9 months of 2018, the territorial agencies of the Rospotrebnadzor of the Russian Federation had revealed 1997 violations. These figures convincingly demonstrate that the market for the production and distribution of DS in Russia is vast, but there are no clear legal mechanisms for regulating this market.

Violations of the mandatory requirements of the law were identified in $77 \%$ of facilities producing DS. During inspections of organizations involved in the implementation of DS (trading enterprises, storage depots, pharmacy chains), violations of the established requirements were found in $47 \%$ of the facilities. 2,412 decisions were issued on imposing an administrative penalty in the form of an administrative fine for 17,114.61 thousand rubles. 1,404 DS batches were withdrawn from commerce. The volume of rejected products amounted to $1,133.16 \mathrm{~kg}$.

These figures convincingly demonstrate the need to study DS as the object of legal regulation, and to search for a mechanism for the effective regulation of the DS civil circulation in the Russian Federation.

\section{Method}

In the research process, we used the following method: comparative and system analysis; scientific research of an object as an element of civil legal relations; synthesis; structural-functional and statistical analysis, as well as the empirical cognition method.

\section{Results}

Russia is a member of the Codex Alimentarius Commission. Codex Alimentarius is a code of accepted international standards and related texts concerning food products presented in a unified format. First of all, these are accepted international standards, guidelines, norms, and rules. The Codex standards are based on reliable scientific data provided by independent international risk assessment bodies or through special consultations organized by the World Health Organization (WHO).

Although the concept of DS is an integral part of the regulatory framework in the field of sanitary and hygienic regulation, the legal doctrine does not contain a scientifically based concept of DS. Legislators define DS as follows: DS are compositions of natural or identical to natural biologically active substances intended for direct intake with food or incorporation into food products to enrich the diet with individual nutritional supplements from plant-based, animal or mineral raw materials, as well as chemical or biologically active substances and their complexes. It seems to us that this definition lacks the most important thing, namely, the purpose of their application. Should there always be a positive effect on the body when taking DS? The history of Russian pharmaceuticals is full of cases where certain medicines did not have any medical effect, and the health of patients improved only due to the placebo effect.

DS registration takes place at the federal level and the state controls all stages of the DS circulation. A study of the dynamics of the development of legislation shows that it follows a chaotic gradual tightening of the order of the DS circulation, and there are no uniform rules for the civil circulation of DS in Russia. As a result, selling DS makes one balance between legal and illegal activities. The similarity of DS to medicines in many respects has predetermined the complex nature of legal relations regulation in the circulation of DS.

The subjects of civil legal relations enter into relations to satisfy their needs. The objects of civil legal relations are various tangible (including material) 
benefits and intangible (ideal) benefits or the process of their creation, which are part of the activities performed by subjects of civil law ${ }^{2}$. DS can have a great impact on human health, not always with positive results. Therefore, the problem of DS turnover is relevant in Russia, as the population's health leaves much to be desired.

Legislators define DS as an object of the material world. This follows from Article 1 of Federal law No. 29-FZ "On food quality and safety" dated 02.01.2000 which defines DS as natural (or identical to natural) biologically active substances.

According to Paragraph 2.1 of Sanitary Rules and norms (SanPiN) 2.3.2.1290 - 03, DS are used as an additional source of food and biologically active substances, to optimize carbohydrate, fat, protein, vitamin and other types of metabolism in various functional states, to normalize and/or improve the functional state of organs and human body systems, including products that provide a restorative, soft diuretic, tonic, sedative and other types of effect under various functional conditions, to reduce the risk of diseases, as well as to normalize the microflora of the gastrointestinal tract as enterosorbents.

The technical regulation of the Customs Union "On food safety" (TR TS 021/2011) defines DS as natural and (or) identical to natural biologically active substances, as well as probiotic microorganisms intended for consumption with food or incorporation into food products. This inclusion of probiotic microorganisms highlights the inconsistency of the concepts defined by various regulatory enactments.

If we turn to the Guidelines of the Chief Sanitary Doctor of Russia on determining the safety and effectiveness of biologically active nutritional supplements, then we will see another definition of DS as compositions of natural or identical to natural biologically active substances intended for direct intake with food or introduction into food products to enrich the diet with individual DS from plant-based, animal or mineral raw materials, as well as chemical or biologically active substances and their combinations $\mathbf{s}^{3,4}$.

Moreover, it is worth noting that legislators introduced DS in two different concepts: as "comestibles" in the law "On the basic norms of state regulation of trade activities in the Russian Federation" and "food products" in the law "On the quality of products".
According to the law "On trading activities", comestibles are products in natural or processed form, which are commercially available and used by humans for food (including baby food, diet food), bottled drinking water, alcoholic beverages, beer and beverages made based on it, soft drinks, chewing gum, nutritional supplements and $\mathrm{DS}^{5}$. Based on this normative act, one can conclude that DS is a kind of comestible.

According to the law "On food quality", food products are products in a natural or processed form used by humans for food (including baby food, diet food), bottled drinking water, alcoholic beverages (including beer), soft drinks, chewing gum, as well as food raw materials, nutritional supplements and $\mathrm{DS}^{6}$.

Based on the foregoing, we can conclude that the concept of food products includes everything that includes the concept of comestibles, except food raw materials. The term "food raw materials" itself does not have legal significance since it is not used in regulatory acts and judicial practice. Therefore, we can say that in general food products and comestibles constitute almost identical concepts ${ }^{7}$. At the same time, a comparison of DS with food products, in our opinion, violates the balance of interests between the consumer and the manufacturer in favor of the latter. This has been repeatedly indicated in the literature more than once 8 . It seems to us that a DS release on the market should be preceded by an investigation of the positive effect of this particular DS.

The dichotomy in the definition of DS in the Russian legislation does not allow fully protecting DS from being confused with other food products or medicines, including international nonproprietary names of medicines (INPNs).

Let us review the question of the correct legal qualifications and the legal regime of DS as an object of civil rights.

In scientific literature, the ability to serve as an object of property turnover (various transactions) and change its owners (holders) is called turnover ratio ${ }^{2}$.From this point of view, all things are divided into three groups (permitted in circulation, restricted in circulation, and prohibited in circulation or withdrawn from circulation). Most of the things belong to the first group, i. e. permitted in circulation. They can freely move from one person to another as a result of civil transactions, without special permission. 
Objects restricted in circulation belong only to certain participants in the turnover. These include ammunition, radioactive substances, etc., or things that are in circulation by special permission of the public authority (for example, currency values, mineral resources, etc.).

The third group of objects withdrawn from circulation consists of things that cannot serve as the subject of transactions and change the owner (Russian Federation or its subjects). These objects, for example, include some land plots that are in federal ownership.

DS are usually classified as objects in free circulation. Legislators do not require a license from legal entities, individual entrepreneurs, and citizens whose activities are associated with the design, construction, reconstruction, operation of organizations for the production of DS, or import and circulation of DS. However, SanPiN2.3.2.1290-03 establishes requirements for the location, arrangement, layout, sanitary condition of organizations involved in the production, import, and circulation of DS, as well as working conditions in their production.

There are requirements for the registration of the new DS. Based on Paragraph 2.8 of SanPiN 2.3.2.129003 , the launch of new DS, production, and circulation of DS is allowed only after confirmation of their compliance with applicable regulatory documents and technical regulations (registration) in the manner prescribed by applicable law. Paragraph 5, Part 1, Article 24 of TR TS 021/2011 classifies DS as specialized food products subject to state registration. According to Part 6, Article 24 of TR TS $021 / 2011$, the fact of state registration of DS is confirmed by the inclusion of information about it in the Unified Register of Specialized Food Products. Thus, on the one hand, legislators classify DS as things that are free to trade, on the other hand, this trade is placed in a tight framework that restricts it. Nevertheless, DS do not appear in Decree No. 179 "On types of products (works, services) and production waste, the free sale of which is prohibited" of the President of the Russian Federation dated February 22, 1992, therefore they can be distributed in free circulation.

Legislators have also established requirements for the sale of DS. For example, DS can be sold in retail by pharmacy organizations (pharmacies, medicine stores, pharmacy kiosks, and others), specialized stores selling dietary products, food stores (special departments, sections, kiosks) (Paragraph 7.4.1 of SanPiN 2.3.2.129003). At the same time, the remote retail sale of DS is not allowed (Letter No. AK/17858/16 "On advertising the remote sale of DS" of the Federal Antimonopoly Service (FAS) of Russia dated 22.03.2016).

Another basis for the classification of objects is their separation into movable and immovable ones. Moreover, the Civil Code of the Russian Federation (CC RF) includes all things not classified by law as real estate in the concept of movable property. Movable property, as a general rule, is not subject to state registration. However, as an exception, legislators may establish the registration of transactions with certain types of movable property (Paragraph 2, Article 164 of the CC RF). Therefore, the fact of registration is not the basis for dividing objects into movable and immovable.

Real estate in Russia includes land, buildings, structures, and all things that are firmly connected with the land, i.e. inseparable from it without disproportionate damage to their economic purpose (immovable by nature). Besides, the $\mathrm{CC}$ RF lists aircraft and sea vessels, inland navigation vessels, and space objects as immovable property subject to state registration. As one can see, real estate is a legal category, and state registration of real estate rights is an integral part of the legal regime of real estate, while movable property registration is an exception to the rule.

DS are registered in the prescribed manner. Rospotrebnadzor reveals the compliance of information about the new DS with regulatory documents and the requirements for the quality of DS (Paragraph 2.2 of SanPiN 2.3.2.1290-03). The fact of state registration of DS is confirmed by the inclusion of information about it in the Unified Register of Specialized Food Products. Information from the Unified Register of Specialized Food Products is publicly available.

The procedure for registering a DS consists of several stages: Formation and submission of a registration dossier for the examination of DS at the Scientific Research Institute of Nutrition of the Russian Academy of Medical Sciences (RAMN);

Product testing and examination;

Drawing up an expert opinion;

Submission of documents and their approval in the agencies of Rospotrebnadzor. 
Since DS are not medicines, they do not undergo large multi-year international independent clinical trials.

Examination of DS includes the assessment of the accompanying documentation of DS, conducting microbiological, sanitary and chemical studies, studying the toxicological and metabolic effects that may be caused by the use of DS, clinical analysis of the effectiveness of DS and a comprehensive assessment of the results based on the data obtained. Thus, DS, being movable property, undergo serious testing and registration as immovable property, but this does not make them real estate.

The CC RF allows for the registration of rights with movable property. Thus, Article 130 of the CC $\mathrm{RF}$ provides for registration on the movable property in cases specified in the law. Paragraph 2, Article 164 of the CC RF establishes state registration of transactions providing for a change in the terms of a registered transaction.

However, in this case, the state registration of DS does not contradict the current legislation of the Russian Federation and it can be assumed that DS, like money and securities, can be attributed to movable property.At the same time, physical properties of objects as a legal regime are not so important for a commodity circulation, namely the ability (impossibility) to make various transactions with these objects, as well as protecting such a regime from possible violations.

TheCCRF protects the results of intellectual activities and equivalent means of individualization of legal entities, goods, works, services. The protection of the results of intellectual activity and means of individualization is carried out under the current legislation of the Russian Federation (Paragraph 2, Article 1225 of the CC RF). For the violation of intellectual property protected by law, various types of liability can arise, such as civil liability (Articles 1253, 1301, 1311, 1472, 1515, 1537 of the CC RF); administrative liability (Article 7.12 of the Administrative Code of the Russian Federation (AC RF) "Violation of copyright and related rights, inventive and patent rights", Article 14.10 of the AC RF "Illegal use of a trademark") and criminal liability (Article 146 of the Criminal Code of the Russian Federation (CrC RF) "Violation of copyright and related rights", Article 147 of the CrC RF "Violation of inventive and patent rights", Article 180 of the CrC RF "Illegal use of a trademark").

Since DS are allowed to be produced and circulated only after confirmation of their registration (Paragraph
2.8 of SanPiN dated 04.17.2003), the right to name the DS, and the right to labeling or designation of goods start to function from the moment of registration of the corresponding biologically active supplement in the Federal Register of Permissible DS. Such a register will allow all consumers to obtain information about the manufacturer, the scope, and expert opinion based on which the certificate was issued. Until the registration, the means of individualization of the right to the name of the supplement is not of an exclusive legal nature. However, it seems to us that in this case, the right to a name can be protected concerning the rules governing unfair competition.

The legal significance of the DS registration is supported by judicial practice. Thus, the court upheld the conclusion that a trademark in the form of a verbal designation cannot be registered to a similar verbal designation of the name of a DS since in this case the trademark was capable of misleading the consumer regarding the location of the manufacturer of the product, and therefore it violated the provisions of Paragraph 3, Article 1483 of the CC RF. In this case, the applicant had applied with priority on December 28, 2009, for registration of the word "TRIBUSTERON" as a trademark. Rospatent refused to register. The applicant appealed against this refusal to a court. All courts supported the decision of Rospatent on the following grounds: a similar designation is used by a limited liability company based on a certificate of the Rospotrebnadzor dated April 17, 2009, and May 26, 2010 , before the priority date of the disputed trademark that the manufacturer wanted to register as a DS name.

Courts, guided by the provisions of Articles 6 and 7 of law No. 3520-1 "On trademarks, service marks and appellations of origin" of the Russian Federation dated September 23, 1992, and Articles 13, 1248, 1483, 1484, 1486 of the CC RF, Paragraph 6 of the Decision of the Plenum of the Supreme Court of the Russian Federation concluded that the designation claimed did not comply with Paragraph 3, Article 1483 of the CC RF.

It is worth noting that the registration of DS in the register protects the right to the name, but DS with a self-registered trademark acquire greater security. Legislators understand a trademark as a designation used to individualize goods, the right to which is certified by a certificate for a trademark (Paragraph 1, Article 1477 of the CC RF). Most manufacturers register verbal, graphic, three-dimensional, and other designations or their combinations as a DS trademark. 
It is also worth noting the practice in the Russian Federation of interpreting norms by the Patent Rights Chamber in addition to court interpretations.

In Russian legislation, as well as in the legislation of most foreign countries, the main sign of trademark eligibility is the presence of distinctive character. At the same time, in judicial practice, it is normal to take into account not only the data of the registers allowing to introduce DS into circulation but also the open data contained in these registers. In this case, the basis for refusal of state registration, the relevant authorities indicate Paragraph 3, Article 1483 of the CC RF, where state registration of designations that are an element or contain an element that is false or is capable of misleading the consumer regarding the product or its manufacturer is not allowed. To such designations, legislators refer to designations that generate in the consumer's mind a false idea of a certain quality of the product, its manufacturer, or place of origin.

The protection capacity of a trademark is limited, as for all means of individualization (for a commercial designation, this is a territorial sphere (Article 1539 of the CC RF), for company names, it is a field of activity (Article 1474 of the CC RF), for trademarks, it is the production of certain groups of goods). In Russia, when registering a trademark, it is necessary to indicate the list of goods according to the International Classification of Goods and Services for the Registration of Marks (hereinafter ICGS) ${ }^{9}$. DS belong to Class 5 of ICGS $^{10}$.

Legislators prohibit registration as trademarks of signs that are identical or similar to the point of confusion with the trademarks of others concerning similar goods and having an earlier priority.

It is widely known that legal protection of a trademark as a means of individualization is provided to classes of goods for which state registration of a designation is requested. If a competitor uses a controversial designation for homogeneous goods, the exclusive right to a trademark is subject to protection under the procedure established in the fourth part of the CC. According to the ICGS, DS belong to Class $5^{11}$. Class 5 of this classification includes pharmaceutical and veterinary medicines; hygiene products for medical purposes; diet food and substances for medical or veterinary purposes, baby food; nutritional supplements for humans and animals; plasters, dressings; materials for dental fillings and manufacturing of dental casts; disinfectants; preparations for the destruction of harmful animals; fungicides, herbicides.

However, even with the inclusion of DS in Class 5 of the ICGS, the law enforcement difficulties are not over. In particular, the question arises about the possibility of applying the registered designation to all types of goods included in one class of ICGS, or about the possibility of equating goods from different classes to DS. On the one hand, the Intellectual property court (IPC) emphasized that in a specific trademark dispute regarding DS, it was necessary to analyze the homogeneity of goods entered into civil commerce by the plaintiff (in a specific case: DS, fruit filler, jelly, ice cream raw materials), products for which trademarks of the defendant had been registered and in respect of which a requirement had been made for the early termination of legal trademark protection (baby food, teas, dietary substances for medical purposes) ${ }^{12}$. When establishing the homogeneity of goods, one needs to determine the fundamental possibility of a consumer having the idea that these goods belong to one manufacturer. To establish the homogeneity of the goods, one takes into account the kind (type) of goods, their purpose, the type of material from which they are made, the conditions for the sale of goods, the circle of consumers, and other characteristics. When establishing the homogeneity of goods (services), courts should take into account the following circumstances: the kind (type) of goods (services), their consumer properties and functional purpose (volume and purpose of use), the type of material from which they are made, complementarity or interchangeability of goods (services), conditions for their sale (including the general point of sale, sale through a retail or wholesale network), the circle of consumers, the traditional or predominant way of using goods (services). However, in another case, in its decision, the Chamber of Patent Disputes Board noted that baby food, or wound dressings, or herbicides and fungicides were not pharmaceuticals, and when deciding on the registration of a trademark, it was not necessary to take into account the uniformity of those products ${ }^{13}$.

Another problem of DS safety is the question if DS are homogeneous to medicines or ordinary food products. How closely is homogeneity related to a particular class of ICGS?

The initial jurisprudence focused on the fact that the homogeneity of goods was determined primarily within the framework of one class of ICGS. Therefore, identical trademarks could be registered for various goods 
included in various classes of ICGS. Thus, the scope of legal protection depends both on the list of specific goods indicated in the trademark certificate and on the general indication of the class of ICGS ${ }^{14}$. At this stage of the development of the institution of trademarks, the concept of "homogeneity" may cover goods related not to the same, but different classes of ICGS.

In addition to the similarity to the degree of mixing, homogeneity of the goods, the name of the DS should not be similar to the well-known active substance (Paragraph 16, Article 4 of the Federal law "On the circulation of medicines" introduces the concept of the INPN of the medicinal product, i. e. the name of the active substance of the pharmaceutical substances recommended by the WHO). It should be noted that judicial practice supports this legal position. Thus, the Decree of the Presidium of the Supreme Arbitration Court of the Russian Federation indicated that the KARNITON trademark was registered for a wide range of goods, including pharmaceuticals, and we can conclude that the registration of this trademark, which is similar to the degree of confusion with the INPN Carnitine used for medicinal products, leads to misleading the consumer who may think that a non-medicinal product marked with this trademark is a medicine $e^{15,16}$.

DS are often presented in a package quite similar to medicines, with similar release forms and similar instructions for use. They are sold through the pharmacy network, sometimes they have a similar composition of active substances. There are frequent cases where the names of DS are indistinguishable or have significant similarities with the names of medicines (usually substances for medical use). The vast majority of dispute cases are related to the means of individualization of DS introduced into commodity circulation.

Thus, DS are recognized in the Russian Federation as objects of civil legal relations, free in civil commerce. Besides, DS are movable property, but legislators have established mandatory registration for entering these objects into commodity circulation. However, DS names can be mixed with other food products, medicines, INPNs of medicines. In this connection, it is necessary to study the life cycle of DS, to develop additional requirements and rules for the rational choice of DS. The practice of assigning names of medicines followed this practice.

What is the DS life cycle? Without a definition of a life cycle, it is difficult to ensure the safe circulation of DS.
Recently, the phrase "life cycle" is increasingly found both in normative acts and in the scientific literature.

The board and council of the Eurasian Economic Commission define the "product life cycle" as all stages of the product's life from the initial development, its circulation until the product ceases to exist ${ }^{17}$ and also defines the concepts of "equipment and (or) coating life cycle"" 18 and other life cycles. The legal concept of "product life cycle" is also contained in other normative acts and is defined as a set of interrelated processes of successive changes in the state of the product from the formation of the initial requirements for the product to the decommissioning of the product, its disposal and (or) dumping ${ }^{19}$.

In the scientific literature, there is currently no single approach to the concept of "life cycle". The number of stages that a product goes through during its life on the market is also not defined in the doctrine $\mathrm{e}^{20,21}$.

Often in normative acts, one can find such terms as "turnover" or "circulation of goods". Under Article 1 of law No. 29-FZ "On food quality and safety" dated January 2, 2000, the turnover of food products means the sale and purchase (including export and import) and other method of food transfer (sale), its storage, and transportation.

Legislators include the following stages in the process of "medicine circulation": development, preclinical studies, clinical trials, examination, state registration, standardization, and quality control, production, manufacturing, storage, transportation, import into the Russian Federation, export from the Russian Federation, advertising, delivery, sale, transfer, use, destruction of medicines. As we see, in this context we are talking only about medicines, which do not include DS.

If we analyze the terms used in the Customs Union, then the circulation of food products means buying and selling and other method of transferring food products in the Customs Union (TR TS 021/2011) ${ }^{22}$.

Thus, the analysis of the current legislation of Russia shows that there is no unity in the regulatory acts of various levels in the use of the terms "turnover" and "circulation".

However, for the legal regulation of the circulation of DS, it is important to trace all stages of the life of 
DS, not only from the moment of sale. If we turn to common vocabulary, the "cycle" is a process consisting of a succession of various stages over a certain period. For any object, it is important to have a period, starting from birth, functioning, and ending with the cessation of existence. Therefore, under the "life cycle" we mean all the processes from the moment of the development of new DS to their introduction into circulation, the turnover itself, and its termination.

In the absence of a normative act on the life cycle of DS from production to disposal, the provisions of various norms of national standards apply, especially the ones concerning food products.

The norms of SanPiN 2.3.2.1290-03 2.3.2. establish requirements for the composition of DS, the development, registration, production, storage, transportation, labeling, sale, disposal, and supervision. The methodological guideline (MG) norms 2.3.2.721-98 are applied at the stages of examination and registration of DS as well as in the development and putting them into production, industrial production, storage, transportation, procurement, import into the country and sale, in the development of regulatory and technical documentation governing the issues of handling DS.

The quality, safety of DS in food, and their ability to exert the effect declared by the manufacturer are determined by their compliance with hygiene standards established by SanPiN 2.3.2.1078-01. Food raw materials must meet the hygiene requirements of the safety and nutritional value of food products. Here one can give two dozen different regulatory acts regulating the life cycle of DS in Russia as an example.

Based on such an extensive regulatory framework that governs the various stages of the life cycle of DS, we have identified the following: development of new DS, examination, state registration, manufacturing (production), storage, transportation, sale, supervision (control) and disposal. The definition of such stages in the life cycle of DS will allow us to study the legal regulation of DS in general and at a specific life stage of DS.

On January 1, 2019, a new national standard of the Russian Federation was introduced, namely "Specialized food products, biologically active nutritional supplements. Method for the determination of quartzetin” GOST R 57990-201723.
Under GOST R 56202-2014, at the earliest stages of development of DS, a risk assessment must be performed to eliminate or minimize potential risks and implement effective control. According to Article 16 of Federal law No. 29-FZ "On food quality and safety" dated 02.01.2000, developers of new food products are obliged to justify the requirements for the quality and safety of the product, develop programs for production control over the quality and safety of products, establish test method, and shelf life. By GOST R 56202-2014, at the earliest stages of development of DS, a risk assessment must be performed to eliminate or minimize potential risks and implement effective control. Thus, when developing DS, the company conducts scientific and technical activities to obtain scientific and technical products for subsequent implementation.

To develop an original medicine, first one needs to decide what the effect of the DS will be (whether it will improve the functioning of the gastrointestinal tract, promote the functioning of the nervous system, etc.) or find a substance that somehow effectively affects the human body. During the initial screening, options are screened in the laboratory, and the non-effective ones are screened out. It is determined whether the selected substance works. If there are few side effects and the tested substance has a positive effect, then the documentation for the registration of a new DS can be prepared.

\section{It is not allowed to buy or sell DS that:}

do not meet the requirements of regulatory documents;

have obvious signs of poor quality that do not raise doubts among representatives of agencies exercising state supervision in the field of ensuring the quality and safety of food products (hereinafter referred to as state supervision agencies) when checking such products, materials, and goods;

do not correspond to the information provided and in respect of which there are reasonable suspicions about their falsification;

do not have established expiration dates (for food products, materials, and goods, for which the establishment of expiration dates is mandatory) or are past their expiration dates; 
do not have labeling containing the information prescribed by law or regulatory documents, or for which there is no such information.

Such DS are recognized as low-quality and dangerous and therefore cannot be sold. They are disposed of or destroyed, withdrawn from circulation by their owner or by order of organizations engaged in state sanitary and epidemiological surveillance, and are also not subject to sale for their intended purpose.

\section{Discussion}

1. In international law, in particular, in Decision No. 880 "On the adoption of technical regulations of the Customs Union "On safe food products" of the Commission of the Customs Union dated December 9, 2011, DS are defined as natural and/or identical to natural biologically active substances, as well as probiotic microorganisms intended for consumption at the same time as food or incorporation into food products. This document also contains implicit criteria for classifying substances as DS. In this regard, the doctrinal and (or) legislative consolidation and refinement require a single concept of DS, which includes the mandatory features (criteria) and allows distinguishing between this object (product) and other (medicines, other food products, etc.).

2. Since currently such concepts used in regulatory legal acts as "releasing DS to the market" and "circulation of DS" have different lexical meanings, it is necessary to use a single terminology in regulatory legal acts that would cover both of these concepts. It seems to us that the wording "releasing DS to the market" which is enshrined in Article 6 of the Directive of the European Parliament and the Council of the EU 2001/83/EC of November 6, 2001, deserves attention. The concept "On the Code of the medicines for human use community" covers not only circulation as trade in the market but also other life cycles of DS.

\section{Conclusion}

As a result of the study and analysis of the regulatory framework and judicial practice, we can draw the following conclusions:

1. DS are recognized as objects of civil legal relations in Russia. They have free turnover, are movable property, and legislators have established mandatory registration for entering these objects into commodity circulation. Requirements for use in the development and production of DS, their import, storage, transportation, and sale in the Russian Federation are established by SanPin.

2. At present, in Russia, there are no clear criteria to clearly distinguish between DS and medicines. DS are often presented in civilian circulation in packaging quite similar to medicines, with similar release forms, and similar instructions for use. They are sold through the pharmacy network, and sometimes they have a similar composition of active substances. This is the reason for the overwhelming majority of cases of disputes concerning means of individualization of DS introduced into civil commerce.

3. In determining the life cycle of DS, the following stages should be distinguished: the development of new DS, examination, state registration, manufacture (production), storage, transportation, sale, supervision (control), and disposal. The definition of such stages in the life cycle of DS will allow us to study the legal regulation of DS in general and at a specific life stage of DS.

4. To develop a new kind of DS, one first needs to decide what this DS will influence (whether it will improve the functioning of the gastrointestinal tract, promote the functioning of the nervous system, etc.) or find a substance that somehow effectively affects the human body. During the initial screening in the laboratory, it is necessary to look at the non-effective options and find out if the selected substance works. If there are few side effects and a positive effect is present, then such a DS can be registered.

5. Since DS are allowed to production and circulation only after their registration, the right to name DS or the right to labeling or designation of goods arises from the moment of such registration in the Federal Register of Permissible DS. Until the registration, the means of individualization of the right to the name of the supplement is not of an exclusive legal nature. However, in this case, the right to the name may be protected based on the law on the Protection of Competition.

\section{Source of Funding: Self}

Conflict of Interest: The authors declare that there is no conflict of interest. 
Ethical Clearance: The experimental plan and procedure of the research were approved by the local commission of All-Russian State University of Justice (RLA of the Ministry of Justice of Russia) № 4-П on November 6, 2020.

\section{References}

1. The official Rospotrebnadzor website. 2020 Available from: https://www.rospotrebnadzor.ru/[Accessed 12th September 2020].

2. Sukhanov EA. Rossiiskoegrazhdanskoepravo [Russian civil law]. Moscow: Statut; 2009.

3. 2.3.2. Pishchevyeproduktyipishchevyedobavki. Opredeleniebezopasnostiieffektivnostibiologicheskiaktivnykhdobavok $\mathrm{k}$ pishche. MetodicheskieukazaniyaMUK 2.3.2.721-98 [2.3.2. Food products and nutritional supplements. Determining the safety and effectiveness of DS. Methodological guidelines MG 2.3.2.721-98]. Moscow:Federal'ny itsentrgossanepidnadzora Minzdrava Rossii;1998. (in Russian)

4. Mokhov AA, Kharitonova YuS. Pravovoirezhimnaimenovaniibiologicheskiaktivnykhdobavok [The legal regime for the names of DS]. Aktualnyeproblemyrossiiskogoprava. 2017;11:103-114. (in Russian)

5. Statya 2 Federalnogozakona No. 381-FZ "Ob osnovakhgosudarstvennogoregulirovaniyatorgovoideyatelnosti v RossiiskoiFederatsii" [Article 2 of Federal law No. 381-FZ "On the basics of state regulation of trade in the Russian Federation"]. December 28, 2009. Available from: https:// rg.ru/2009/12/30/torgovlya-dok.html[Accessed 12th September 2020].

6. Statya 1 Federalnogozakona No. 29-FZ “O kachestveibezopasnostipishchevykhproduktov" [Article 1 of Federal law No. 29-FZ "On food quality and safety"]. January 2, 2000. Available from: https:// rg.ru/2000/01/02/produkty-dok.html [Accessed 12th September 2020].

7. Maslova VA. Ponyatie "prodovolstvennyitovar" i ego yuridicheskoeznacheniedlyadogovorovmezhdutorgovymisetyamiipostavshchikami [The concept of "comestible" and its legal meaning for contracts between retail chains and suppliers]. SPS "KonsultantPlyus" [Consultant Plus legal reference system]; 2017. (in Russian)

8. SvirinYuA, Kulakov VV, Mokhov AA, Shestov
$\mathrm{CN}$, Sorokin VP. Balance of interest as a Principle of Civil law: same Aspects of Legal Conscionsness. J Adv Res law Econ. 2019;10(3):940-947.

9. Rospatent. Mezhdunarodnayaklassifikatsiyatovaroviuslugdlyaregistratsiiznakov (MKTU) [International Classification of Goods and Services for the Registration of Marks (ICGS)]. 11th ed. Moscow: FGBU FIPS Rospatent; 2018. (in Russian)

10. Informatsionnoe pismo Rospatenta ot 05.11.2008, Postanovlenie Prezidiuma VAS RF No. 8817/11 [Information letter of Rospatent dated 05.11.2008, Resolution No. 8817/11]. November 29, 2011. Available from: http://www.arbitr.ru/bras.net/f. aspx?id_casedoc=1_1_33ea2549-ae5a-4019-b27bd83a68ac0821[Accessed 2020 September 12].

11. Rospatent. Mezhdunarodnayaklassifikatsiyatovaroviuslugdlyaregistratsiiznakov (MKTU) [International Classification of Goods and Services for the Registration of Marks (ICGS)]. 10th ed. Moscow: FGBU FIPS Rospatent; 2015. (in Russian)

12. PostanovleniePrezidiumaSuda po intellektualnympravam No S01-575/2014 po delu No SIP-434/2013 [Decision No. C01-575/2014 in case No. СИП-434/2013 of the Presidium of the IPC].July 30, 2014. Available from: https:// kad.arbitr.ru/Document/Pdf/2c213a0b-2a244605-bc1b-3afb675ac78a/90de961e-a8c4-4ca8b8e1-ffe006bfd96c/SIP-434-2013_20140730_ Reshenija_i_postanovlenija.pdf[Accessed 2020 September 12].

13. DzhemarkyanVYu. 500 voprosov po tovarnymznakam: razyasneniyapravoprimenitelnoipraktiki [500 questions on trademarks: explanation of law implementation practice]. SPS Garant [Garant legal reference system]; 2015. (in Russian)

14. Punkt 2 InformatsionnogopismaPrezidiuma VAS RF No. 19 "Obzorpraktikirazresheniyasporov, svyazannykh s zashchitoiprav na tovarnyiznak" [Paragraph 2 of Information letter No. 19 "Overview of the practice of resolving disputes related to the protection of trademark rights" of the Presidium of the Supreme Arbitration Court of the Russian Federation]. July 29, 1997. Available from: http://www. arbitr.ru/arxiv/vas_info_letter/3032.html[Accessed 2020 September 12].

15. Postanovlenie Prezidiuma VAS RF No $12436 / 11$ po delu No A40-66999/10-26-563 [Resolution No. $12436 / 11$ in case No. A40-66999/10-26-563 of the Presidium of the Supreme Arbitration Court 
of the Russian Federation]. February 28, 2012. Available from: http://www.arbitr.ru/bras.net/f. aspx?id_casedoc $=1$ 1_430edd4f-f28c-49bc-a43429da84d97da0[Accessed 2020 September 12]

16. Postanovlenie Arbitrazhnogo suda Moskovskogo okruga po delu No. A40-97336/2017 [, Resolution of the Arbitration Court of the Moscow District in case No. A40-97336/2017]. March 22, 2018. Available from: https://kad.arbitr.ru/Document/ Pdf/df39b2f0-8325-46cb-b733-2be535b47efb/ f411409c-9eab-41b4-81b4-5e5bedc290a9/A4097336-2017_20180322_Reshenija_i_postanovlenija.pdf[Accessed2020 September 12].

17. Punkt 7 RekomendatsiiKollegiiEvraziiskoiekonomicheskoikomissii No. 19 "O rukovodstve po validatsiiprotsessaproizvodstvalekarstvennykhpreparatovdlyameditsinskogoprimeneniya" [Paragraph 7 of Recommendation No. 19 "On the guidelines for validating the production process of medicines for medical use" of the Board of the Eurasian Economic Commission]. September 26, 2017.Available from: https://docs.eaeunion.org/ docs/ru-ru/01414949/clcr_28092017_19[Accessed 2020 September 12].

18. ReshenieSovetaEvraziiskoiekonomicheskoikomissii No. 21 "O tekhnicheskomreglamenteEvraziiskogoekonomicheskogosoyuza "O bezopasnostioborudovaniyadlyadetskikhigrovykhploshchadok" [Decision No. 21 "On the technical regulation of the Eurasian Economic Union 'On the safety of equipment for children's playgrounds"'of the Council of the Eurasian Economic Commission]. May 17, 2017. Available from: https://sudact.ru/law/reshenie-soveta-evraziiskoi-ekonomicheskoi-komissii-ot-17052017/tr-eaes-0422017/ [Accessed2020 September 12].
19. PostanovleniePravitelstva RF No. 544 "Ob osobennostyakhPravilnadlezhashcheiproizvodstvennoipraktikiEvraziiskogoekonomicheskogosoyuza" [Decree No. 544 "On the features of the rules of good manufacturing practice of the Eurasian Economic Union" of the Government of the Russian Federation]. June 15, 2016. Available from: www.pravo. gov.ru[Accessed 2020 September 12].

20. Kotler Ph. Marketing menedzhment [Marketing Management]. 12th edition. St. Petersburg: Piter; 2007. (in Russian)

21. Sabinina AL. Strukturazhiznennogotsiklaproduktsiivoennogonaznacheniyakakfaktorpovysheniyaurovnyaeekonkurentosposobnosti [The life cycle structure of military products as a factor in increasing the level of their competitiveness]. Ekonomicheskii analiz: teoriyaipraktika. 2004;5:40-47. (in Russian)

22. ReshenieKomissiiTamozhennogosoyuza No 880 "O prinyatiitekhnicheskogoreglamentaTamozhennogosoyuza "O bezopasnostipishchevoiproduktsii" [Decision No. 880 "On the adoption of technical regulations of the Customs Union "On the safety of food products" of the Commission of the Customs Union]. December 9, 2011. Available from: www. tsouz.ru[Accessed 2020 September 12].

23. PrikazRosstandarta No. 1826-ст [Rosstandart order No. 1826-ст.]. November 24, 2017. Available from: https://legalacts.ru/doc/prikaz-rosstandartaot-24112017-n-1826-st-ob-utverzhdenii-natsionalnogo/[Accessed 12th September 2020]. 